DOI: 10.17951/lrp. 2017.36.4.153

\author{
EWA FALKIEWiCZ \\ Uniwersytet Technologiczno-Humanistyczny w Radomiu \\ MONIKA MAJ \\ Uniwersytet Technologiczno-Humanistyczny w Radomiu
}

\title{
BIG DATA - STUDIA PRZYSZŁOŚCI
}

\begin{abstract}
Streszczenie: Celem pracy jest pokazanie, jak wielką przyszłość dają w dzisiejszych czasach studia na kierunku analiza danych. Tekst prezentuje wyniki badań przeprowadzonych przez autorów. Pokazuje, w jakim stopniu maturzyści i studenci są zaznajomieni z najnowszymi osiągnięciami technologii IT.
\end{abstract}

Słowa kluczowe: big data, analiza danych, kształcenie, analityk danych

\section{WPROWADZENIE}

Współczesny rozwój technologii wymaga od nas ciągłego rozwoju i monitorowania wciąż zachodzących zmian. W związku $\mathrm{z}$ dynamicznym postępem technicznym istnieje potrzeba udoskonalania, dopracowywania i modernizowania procesu kształcenia. Na różnych etapach edukacji przebiega to w inny sposób i jest inaczej wdrażane. Możemy zauważyć ogromny wpływ technologii informacyjnych na proces kształcenia. Niewątpliwie nadeszły czasy, w których obecność tabletów i e-podręczników na lekcjach staje się coraz bardziej powszechna. W przypadku szkolnictwa wyższego zmiany zachodzące w procesie kształcenia studentów mogą przejawiać się chociażby w tworzeniu nowych kierunków studiów. Widząc potrzebę edukacji w zakresie informatyki, uczelnie starają się dostosować ofertę do oczekiwań rynku pracy. Powstaje wiele nowych kierunków, które mają na celu kształcenie jak najlepszych specjalistów. Absolwenci, kończąc takie studia, mogą liczyć na dobrze płatną i satysfakcjonującą pracę. Niniejszy artykuł jest próbą opisu takiego właśnie kierunku. Dodatkowo przeprowadzone zostały badania dotyczące kierunku big data - analiza danych. 


\section{OFERTA DYDAKTYCZNA}

Wydaje się, że na dzień dzisiejszy najbardziej atrakcyjną ofertą są studia na kierunku analiza danych - big data prowadzone w Szkole Głównej Handlowej w Warszawie. Pierwsza edycja studiów podyplomowych inżynieria danych - big data rozpoczęła się w semestrze zimowym 2014/2015 (www1). Od semestru letniego 2014/2015 uruchomiono studia magisterskie analiza danych - big data (www2).

Naukowcy kształcą specjalistów w zakresie pozyskiwania danych z różnych źródeł oraz ich analizy, przekazują zaawansowaną wiedzę i kompetencje umożliwiające podjęcie pracy zawodowej na stanowisku specjalisty zaawansowanej analizy danych w przedsiębiorstwach produkcyjnych, bankach, firmach ubezpieczeniowych i telekomunikacyjnych, administracji publicznej oraz centrach badawczych wyspecjalizowanych w zaawansowanej analityce danych. W poniższej tabeli przedstawimy efekty kształcenia, jakie osiągają absolwenci kierunku analiza danych - big data.

Tabela1. Efekty kształcenia absolwentów kierunku analiza danych - big data

\begin{tabular}{|l|l|l|}
\hline \multicolumn{1}{|c|}{ Wiedza } & \multicolumn{1}{|c|}{ Umiejętności } & \multicolumn{1}{c|}{ Kompetencje społeczne } \\
\hline $\begin{array}{l}\text { z zakresu informatyki odnośnie } \\
\text { metod pozyskiwania, porządko- } \\
\text { wania, przechowywania i prze- } \\
\text { twarzania ustrukturalizowanych } \\
\text { i nieustrukturalizowanych } \\
\text { danych }\end{array}$ & $\begin{array}{l}\text { student potrafi pozyská dane } \\
\text { z różnch źródeł (bazy danych, } \\
\text { ne, sieci społecznościowe, dane } \\
\text { sensoryczne i geolokacyjne) }\end{array}$ & $\begin{array}{l}\text { student rozumie potrzebę } \\
\text { i potrafi korzystać z podejścia } \\
\text { ilościowego dla lepszego postrze- } \\
\text { gania, opisu i analizy otaczającej } \\
\text { rzeczywistości ekonomicznej, } \\
\text { społecznej, biznesowej }\end{array}$ \\
\hline $\begin{array}{l}\text { w zakresie złożonych struktur } \\
\text { danych, a także jej reprezentacji } \\
\text { w systemach informatycznych }\end{array}$ & $\begin{array}{l}\text { student potrafi budować zapy- } \\
\text { tania do SQL-owych, jak i nie } \\
\text { SQL-owych baz danych }\end{array}$ & $\begin{array}{l}\text { student daje przykład etycznych } \\
\text { zachowań zawodowych }\end{array}$ \\
\hline $\begin{array}{l}\text { z zakresu matematycznych, } \\
\text { statystycznych i informatycznych } \\
\text { metod i narzędzi analizy danych } \\
\text { niezbędnych w analizie zjawisk } \\
\text { społecznych i gospodarczych }\end{array}$ & $\begin{array}{l}\text { student potrafi przygotować dane } \\
\text { do analizy }\end{array}$ & $\begin{array}{l}\text { student jest świadomy odpowie- } \\
\text { dzialności zawodowej w pracy } \\
\text { w podmiotach gospodarczych } \\
\text { i instytucjach, w których wyma- } \\
\text { gane jest stosowanie narzędzi } \\
\text { matematycznych, statystycznych, } \\
\text { ekonometrycznych i informa- } \\
\text { tycznych }\end{array}$ \\
\hline $\begin{array}{l}\text { z zakresu metod i narzędzi budo- } \\
\text { wy modeli prognostycznych } \\
\text { i symulacyjnych z odniesieniem } \\
\text { do zjawisk społecznych i gospo- } \\
\text { darczych }\end{array}$ & $\begin{array}{l}\text { student potrafi budować modele } \\
\text { analizy danych w oparciu o róż- } \\
\text { norodne narzędzia statystyczne, } \\
\text { matematyczne i informatyczne } \\
\text { oraz wyciągać wnioski i formuło- } \\
\text { wać sądy na ich podstawie }\end{array}$ & $\begin{array}{l}\text { student rozumie własną } \\
\text { i zbiorową odpowiedzialnośćc } \\
\text { za ważne wydarzenia społeczne } \\
\text { i polityczne }\end{array}$ \\
\hline
\end{tabular}




\begin{tabular}{|c|c|c|}
\hline Wiedza & Umiejętności & Kompetencje społeczne \\
\hline $\begin{array}{l}\text { w zakresie metod opracowywania } \\
\text { wyników analizy danych }\end{array}$ & $\begin{array}{l}\text { - student potrafi projektować } \\
\text { badania reprezentacyjne } \\
\text { i prowadzić analizy statystycz- } \\
\text { ne przy analizowaniu zjawisk } \\
\text { i procesów gospodarczych; } \\
\text { - student potrafi analizo- } \\
\text { wać dane wielowymiarowe, } \\
\text { stosować metody analizy } \\
\text { wielowymiarowej w badaniach } \\
\text { ekonomiczno-biznesowych } \\
\text { (rynkowych i marketingowych) } \\
\text { oraz w badaniach społecznych; } \\
\text { - student potrafi analizować } \\
\text { dane przestrzenne; } \\
\text { - student potrafi dostosować } \\
\text { metody prezentacji wyników } \\
\text { analiz do wymagań odbiorców; } \\
\text { - student potrafi implementować } \\
\text { systemy informatyczne oparte } \\
\text { na przetwarzaniu wiedzy; } \\
\text { - tudent potrafi implementować } \\
\text { wyniki analizy danych w roz- } \\
\text { wiązaniach biznesowych; } \\
\text { - student potrafi biegle posługi- } \\
\text { wać się przynajmniej jednym } \\
\text { językiem obcym, prezentować } \\
\text { wyniki swojej pracy w formie } \\
\text { ustnej i pisemnej w języku } \\
\text { polskim i obcym }\end{array}$ & \\
\hline
\end{tabular}

Źródło: www3

\section{BIG DATA W TEORII I PRAKTYCE}

W celu pełniejszego zrozumienia danych przedstawionych w powyższej tabeli warto odpowiedzieć sobie na pytanie, czym jest big data. Otóż jest to termin odnoszący się do dużych, zmiennych i różnorodnych zbiorów danych. Ich przetwarzanie i analiza jest trudna, ale jednocześnie wartościowa, bo może prowadzić do zdobycia nowej wiedzy. W praktyce pojęcie dużego zbioru danych jest względne. Oznacza bowiem sytuację, gdy zbioru nie da się przetwarzać przy użyciu trywialnych, powszechnie dostępnych metod. W zależności od branży i stopnia złożoności algorytmu możemy mówić o terabajtach lub petabajtach (np. analiza zderzeń cząstek elementarnych w fizyce wysokich energii). W innych zastosowaniach mogą to być megabajty bądź gigabajty (np. porównywanie billingów telefonicznych w telekomunikacji). Big data 
ma zastosowanie wszędzie tam, gdzie dużej ilości danych cyfrowych towarzyszy potrzeba zdobywania nowych informacji lub wiedzy. Szczególne znaczenie ma tutaj wzrost dostępności do Internetu oraz usług świadczonych drogą elektroniczną. Są one w naturalny sposób przystosowane do wykorzystywania baz danych.

Już w 2001 roku META Group (obecnie Gartner) opublikowała raport, w którym opisała big data w modelu $3 \mathrm{~V}$ :

1) duża ilość danych (ang. volume),

2) duża zmienność danych (ang. velocity),

3) duża różnorodność danych (ang. variety).

Model ten został uzupełniony o ocenę (weryfikację) (ang. value) posiadanych danych. Powstał w ten sposób model 4V. Stosując ten model, powinniśmy:

1) wykorzystać wewnętrzne (własne) zasoby danych;

2) wnioskować (umiejętnie stosować techniki analityczne);

3) wzbogacać własne dane o informacje z rynku (wykorzystanie słowników i baz referencyjnych);

4) weryfikować hipotezy i wnioski.

W roku 2012 Gartner uzupełnił podaną wcześniej definicję, wskazując, iż big data to zbiory informacji o dużej objętości, dużej zmienności lub dużej różnorodności, które wymagają nowych form przetwarzania w celu wspomagania podejmowania decyzji, odkrywania nowych zjawisk oraz optymalizacji procesów.

Big data to pobieranie, przetwarzanie, analizowanie i wizualizacja danych. Firmy pobierają legalnie informacje z różnych źródeł, porównują je, analizują, a następnie wyciągają wnioski. Na końcu powstaje produkt finalny: obraz sytuacji bądź też człowieka, który pomaga firmom oraz instytucjom w ich działalności. Jest to zatem cały proces polegający na pewnym wykorzystaniu danych. Błędne jest twierdzenie, że jest to proces gromadzenia czy pobierania danych. Jakie mogą być źródła danych? Odpowiadając na to pytanie, posłużymy się przykładem banków. Dla nich źródłami danych będą wszelkie nasze działania związane z kontem, czyli jak, kiedy i za co płacimy, czy dokonujemy pewnych zakupów regularnie, jakie mamy wpływy na konto. Wszystkie te dane bank gromadzi w naturalny sposób, pokazuje nam je po zalogowaniu na konto. Źródłem mogą być także dane dostępne w Internecie, w tym w serwisach społecznościowych, ale też dane z wszelkiego rodzaju systemów informacji marketingowej czy baz danych klientów. Popularny w dzisiejszych czasach Facebook nie udostępnia danych firmom w jakiś specjalny sposób. Istnieje jednak możliwość pobierania danych dotyczących niektórych aktywności w miejscach i na profilach publicznych oraz za zgodą użytkownika przez aplikacje. Okazuje się, że większość z nas udostępnia prawie całe swoje życie, korzystając z Facebooka. Wszyscy powinniśmy zastanowić się, na ile sami zdradzamy firmom, kim jesteśmy? Instalując dziesiątki aplikacji, za każdym razem 
wyrażamy zgodę na dostęp danej aplikacji do naszych danych. Mogą to być nie tylko wyniki wyszukiwania, ale też kontakty, SMS-y, e-maile.

\section{BADANIA}

W celu weryfikacji wiedzy dotyczącej big data przeprowadzono ankietę składającą się z 10 niżej przedstawionych pytań.

1. Czy spotkałeś się z określeniem big data?
a) tak
b) nie

2. Skąd dowiedziałeś się o big data?
a) media
b) internet
c) znajomi
d) szkoła, uczelnia

3. Kim jest data scientist?
a) naukowcem
b) informatykiem
c) analitykiem danych
d) matematykiem
e) nie wiem

4. Która z polskich uczelni prowadzi studia na kierunku analiza danych big data?
a) Politechnika Warszawska
b) Politechnika Wrocławska
c) $\mathrm{SGH}$
d) AGH
e) nie wiem

5. Wiedzą z jakich dziedzin może się wykazać osoba, która ukończy studia big data?
a) ekonomia
b) informatyka
c) statystyka
d) nie wiem

6. Absolwent studiów big data może pracować w:
a) przedsiębiorstwie produkcyjnym
b) banku
c) firmie ubezpieczeniowej 

d) firmie telekomunikacyjnej
e) administracji publicznej
f) centrum badawczym
g) szkole
h) nie wiem

7. Czy uważasz, że studia big data mają przyszłość?
a) tak
b) nie
c) nie wiem

8. Czy byłbyś zainteresowany podjęciem studiów o takim kierunku?
a) tak
b) nie
c) nie wiem

9. Jesteś:
a) uczniem szkoły ponadgimnazjalnej
b) studentem kierunku technicznego
c) studentem informatyki
d) studentem matematyki
e) studentem ekonomii
f) studentem kierunku humanistycznego

10. Jesteś:
a) kobietą
b) mężczyzną

Badaniem zostało objętych 130 osób. Wśród nich było 60 tegorocznych maturzystów warszawskich szkół ponadgimnazjalnych (33 kobiety i 27 mężczyzn), 30 studentów pierwszego roku kierunków technicznych (14 kobiet i 16 mężczyzn) i 40 studentów kierunku informatyka (5 kobiet i 35 mężczyzn). Studenci zostali wybrani spośród żaków studiujących na Politechnice Warszawskiej i Uniwersytecie Technologiczno-Humanistycznym w Radomiu. W poniższych opisach oznaczono: 1 - maturzyści, 2 - studenci kierunków technicznych, 3 -studenci informatyki. Badania przeprowadzono w grudniu 2015 roku. Na wstępie respondenci zostali poinformowani o naukowym i praktyczno-użytkowym celu badań oraz o ich anonimowym charakterze.

Pierwsze z pytań pokazało, jak niewiele osób spotkało się z określeniem big data. Poniżej przedstawiamy zestawienie udzielonych odpowiedzi. 


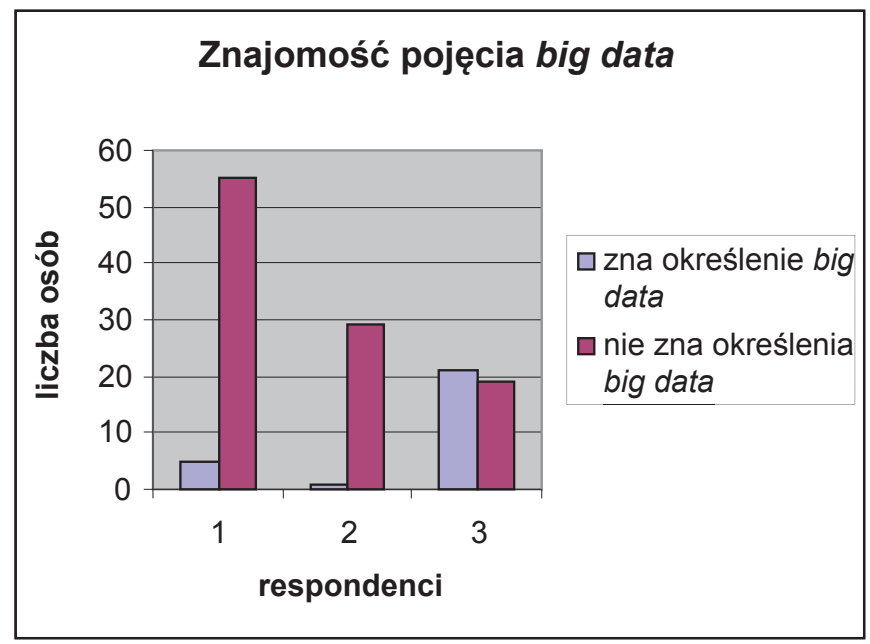

Rysunek 1. Znajomość pojęcia big data

Źródło: opracowanie własne

Okazuje się, że jedynie 20,77\% respondentów spotkało się z pojęciem big data. Najwięcej, bo aż 77,(7)\% z nich to studenci informatyki. Tylko jeden ze studentów kierunków technicznych spotkał się z tym określeniem. Spośród osób, które znają pojęcie big data, aż $61 \%$ jako źródło wiedzy podaje Internet. Na kolejnych pozycjach plasują się: szkoła i uczelnia (21\%) i znajomi (11\%). Na ostatnim miejscu znalazły się media (7\%).

\section{Źródła wiedzy o big data}

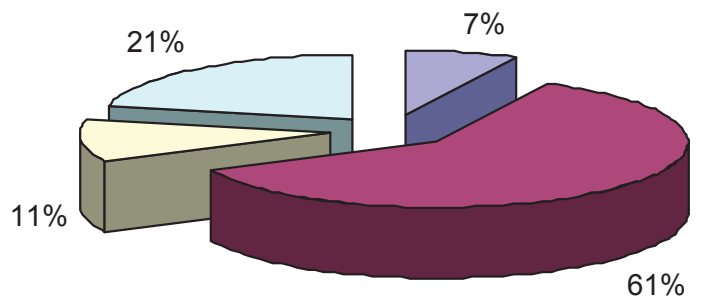

$\square$ media

$\square$ internet

$\square$ znajomi

$\square$ szkoła, uczelnia

Rysunek 2. Źródła wiedzy o big data

Źródło: opracowanie własne 
Kolejne pytanie dotyczyło znajomości pojęcia data scientist. Poniżej prezentujemy zestawienie podanych odpowiedzi.

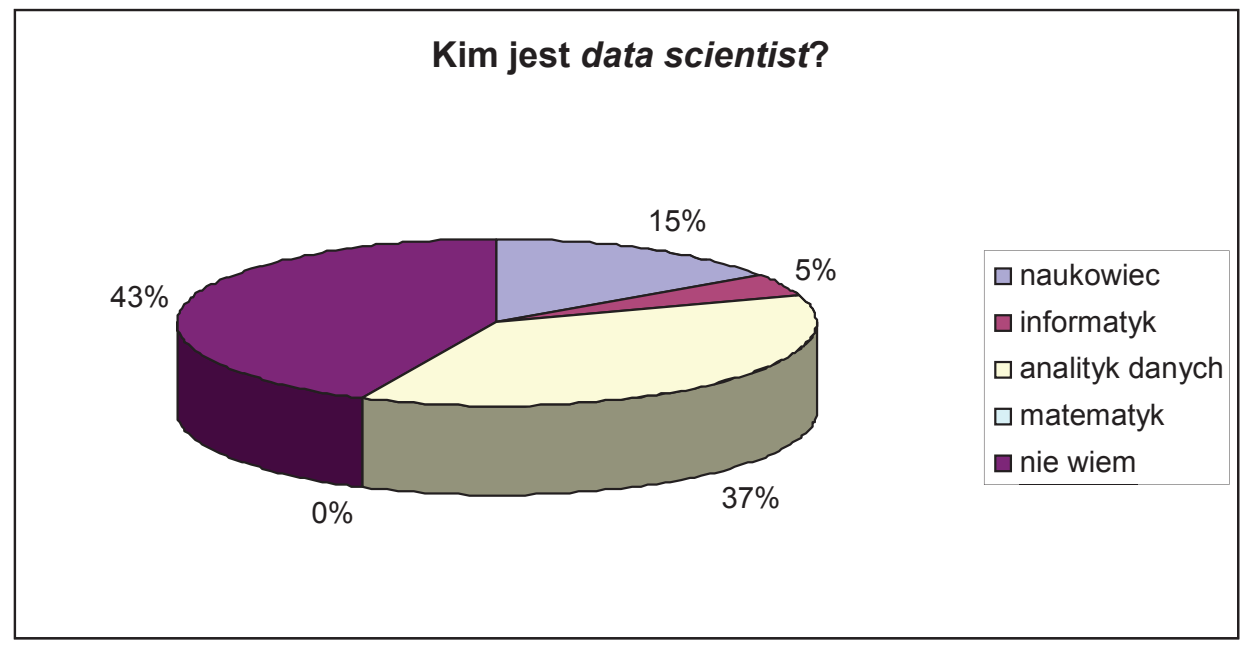

Rysunek 3. Polskie określenie data scientist

Źródło: opracowanie własne

Okazuje się, że $37 \%$ odpowiedzi wskazuje na utożsamienie pojęcia data scientist $\mathrm{z}$ analitykiem danych. 15\% respondentów twierdzi, że wspomniana nazwa odnosi się do naukowca, natomiast $5 \%$ osób twierdzi, że jest to informatyk. Aż 43\% ankietowanych nie potrafiło dopasować określenia data scientist do wymienionych zawodów. Problemem okazało się także kolejne pytanie dotyczące polskiej uczelni, która prowadzi studia na kierunku analiza danych - big data. Aż 59,93\% respondentów nie znało odpowiedzi. Spośród tych, którzy zdecydowali się wybrać jedną z wymienionych uczelni, 51,02\% wskazało na Politechnikę Warszawską, 22,45\% - SGH, 20,41\% - AGH i 6,12\% - Politechnikę Wrocławską. Niestety okazuje się, że studenci nie popisali się znajomością ofert uczelni wyższych. 43,75\% warszawskich maturzystów, wybierając SGH (spośród tych, którzy zaznaczyli polską uczelnię), pokazało, że interesują się możliwościami studiowania i znają propozycje polskich uczelni. Poniżej przedstawiamy zestawienie odpowiedzi na pytanie, na której z wymienionych uczelni możemy studiować analizę danych. 


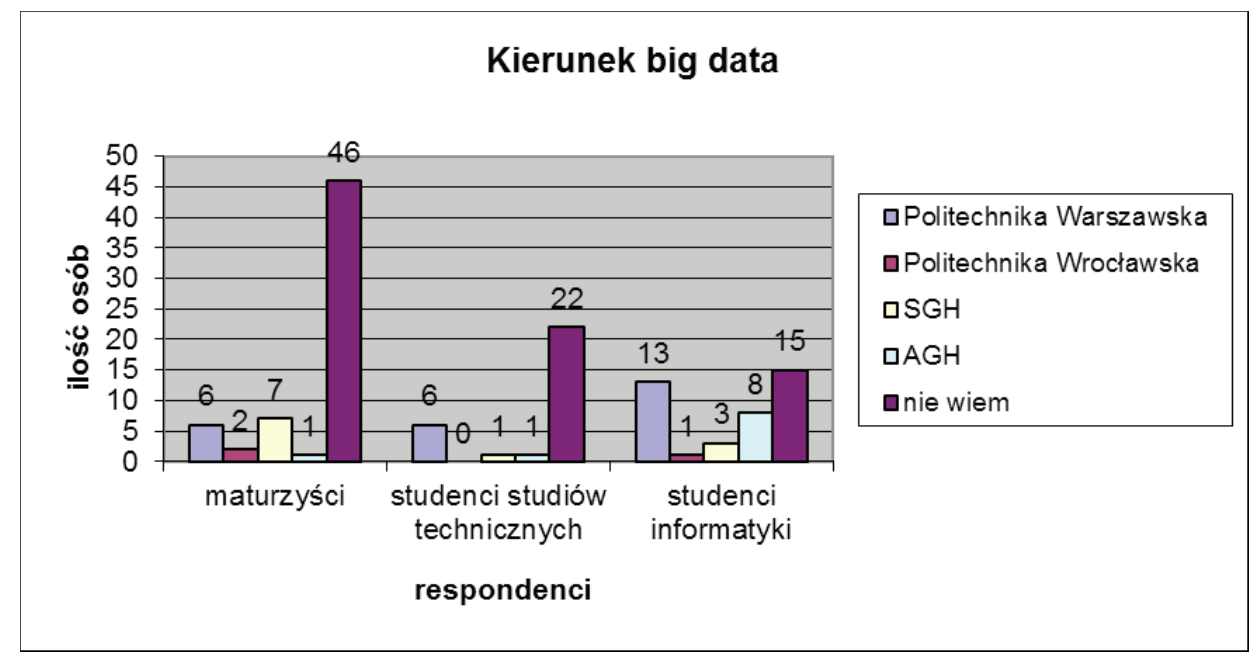

Rysunek 4. Kierunek big data na polskich uczelniach

Źródło: opracowanie własne

Przyjrzyjmy się teraz wiedzy, jaką może wykazać się osoba kończąca studia na kierunku big data.

\section{Wiedza studenta kończącego studia na kierunku big data}

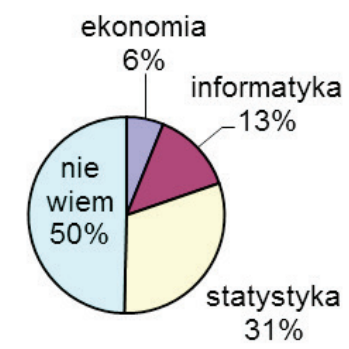

口ekonomia
घinformatyka
口statystyka
anie wiem

Rysunek 5. Wiedza absolwenta kierunku big data

Źródło: opracowanie własne 
W świetle przeprowadzonych badań absolwent kierunku analiza danych jest specjalistą ze statystyki (31\%), informatyki (14\%) i ekonomii (6\%). Niestety aż $49 \%$ ankietowanych nie dysponuje wiedzą na temat umiejętności specjalisty z zakresu big data. W przypadku pytania o rynek pracy dla absolwenta omawianego przez nas kierunku studiów odpowiedzi przedstawiały się następująco:

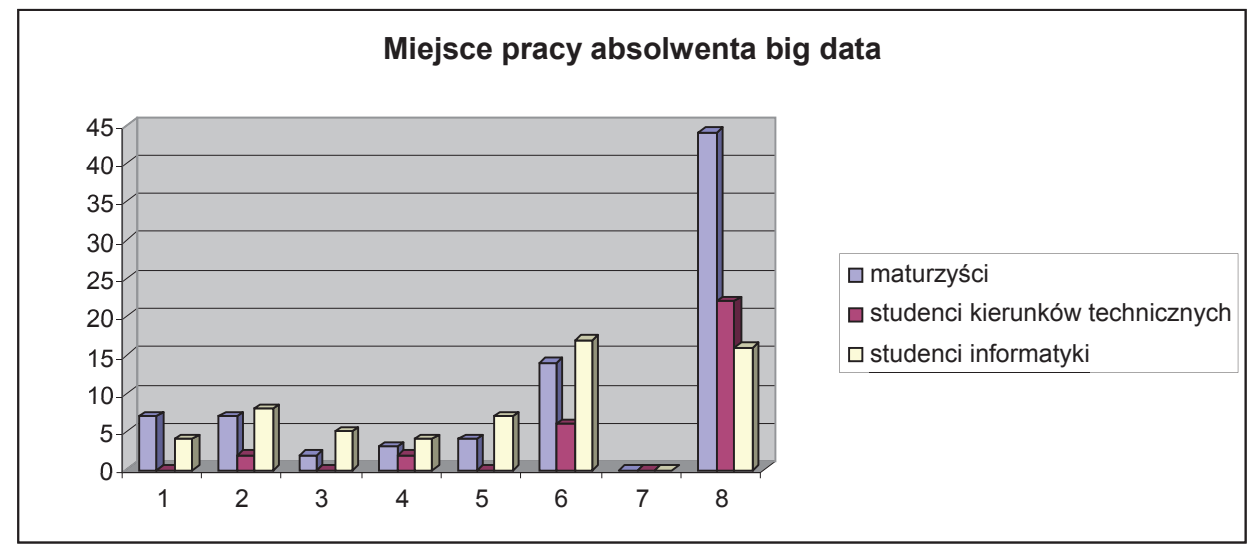

Rysunek 6. Miejsce pracy absolwenta big data

Źródło: opracowanie własne

W powyższej tabeli przyjmujemy: 1 - przedsiębiorstwo produkcyjne, 2 - bank, 3 -firma ubezpieczeniowa, 4 - firma telekomunikacyjna, 5 - administracja publiczna, 6 - centrum badawcze, 7 - szkoła, 8 - nie wiem. Wyniki badań pokazują, że $68,9 \%$ badanych nie wie, gdzie może pracować absolwent kierunku analiza danych (53,66\% to maturzyści, 26,83\% - studenci kierunków technicznych, $19,51 \%$ - studenci informatyki). Najwięcej, bo aż $21,26 \%$, respondentów jest zdania, że miejscem pracy ludzi o rozważanych umiejętnościach może być centrum badawcze. Na kolejnych miejscach plasują się: bank (9,77\%), przedsiębiorstwo produkcyjne i administracja publiczna (po 6,32\%), firma telekomunikacyjna $(5,17 \%)$ oraz firma ubezpieczeniowa (4,02\%). Żaden $\mathrm{z}$ ankietowanych nie brał pod uwagę szkoły jako miejsca pracy absolwenta big data.

Na koniec omówimy odpowiedzi respondentów dotyczące przyszłości studiów big data oraz zainteresowanie tymi studiami. Poniżej przedstawiamy zastawienie wyników. 


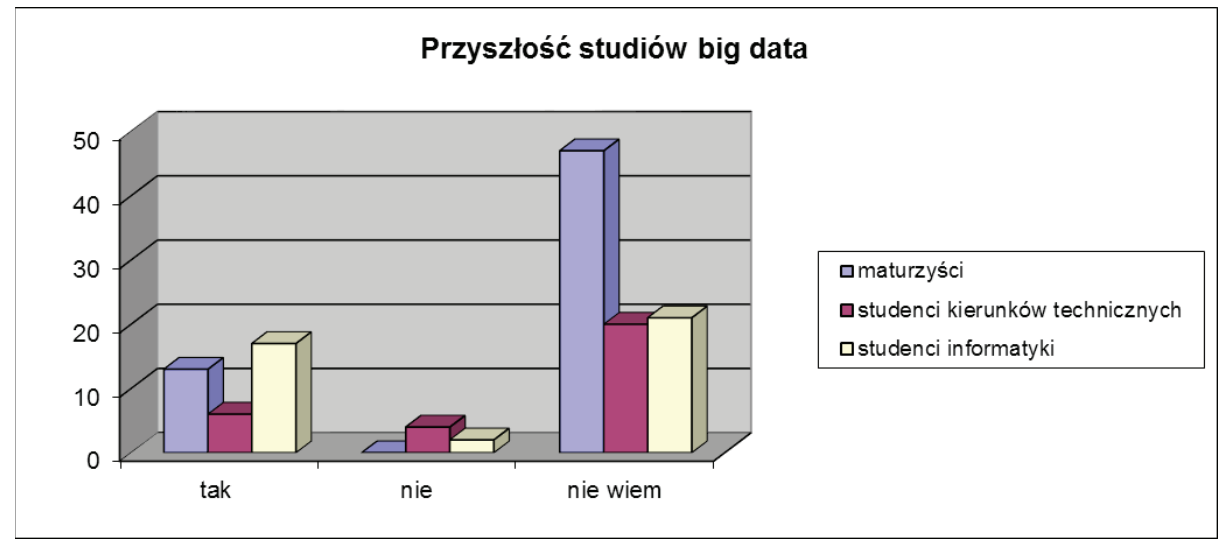

Rysunek 7. Czy studia na kierunku big data mają przyszłość?

Źródło: opracowanie własne

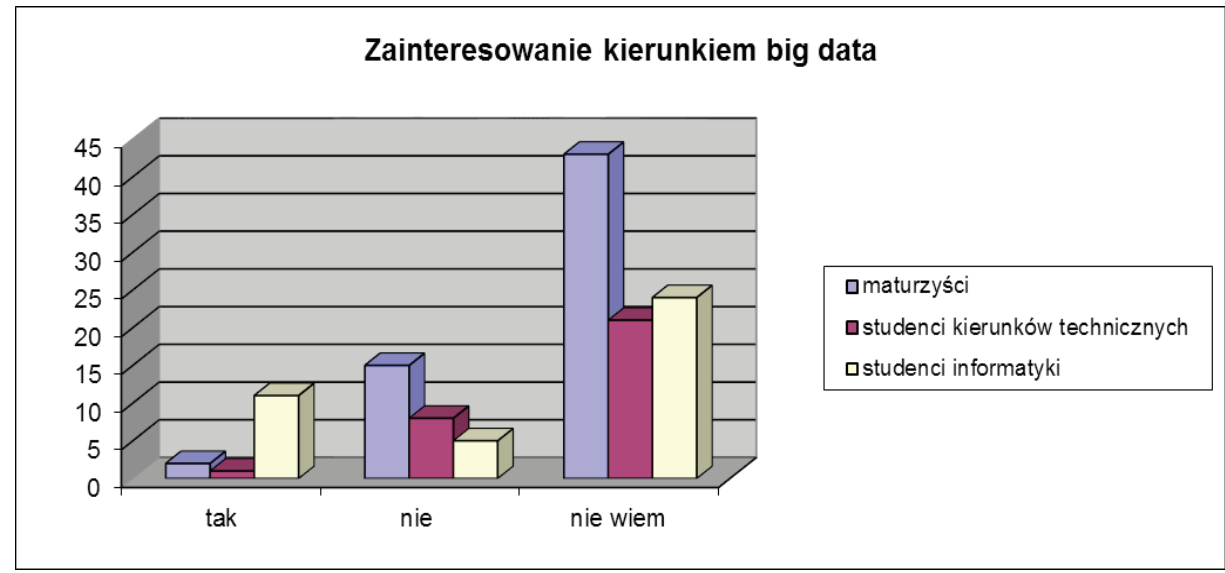

Rysunek 8. Zainteresowanie kierunkiem big data

Źródło: opracowanie własne

Tylko 27,69\% respondentów jest zdania, że studia na kierunku analiza danych mają przyszłość, natomiast aż $67,77 \%$ nie ma na ten temat zdania. Co do zainteresowania studiami na tym kierunku to jedynie $10,77 \%$ ankietowanych chciałoby podjąć naukę na kierunku big data. Zdecydowani przeciwnicy to aż $21,54 \%$ badanych. 


\section{WNIOSKI}

Śledząc odpowiedzi na pytania zawarte w ankiecie, nie sposób nie oprzeć się wrażeniu, że respondenci nie są do końca osobami zainteresowanymi najnowszymi trendami wykorzystania wszechobecnej technologii IT. Być może wynikiem ich niewiedzy jest zbyt mała świadomość społeczeństwa odnośnie konieczności obróbki i przetwarzania danych. To, że studia na kierunkach big data przeżywają swój złoty wiek jest zapewne wynikiem ogromnego zapotrzebowania na specjalistów z tej dziedziny. Coraz więcej firm i instytucji potrzebuje osób, które potrafią z ogromnej ilości danych pozostawionych przez nas w sieci wyciągnąć odpowiednie wnioski. Opracowanie big data, ich odpowiednia interpretacja stają się kluczem do sukcesu na rynku gospodarczym. Żyjąc w dobie gospodarki opartej na wiedzy, należy ją jak najlepiej wykorzystać, aby zapewnić firmie jak najbardziej dynamiczny rozwój. Niestety wyniki naszych badań nie pozostawiają złudzeń co do niewiedzy respondentów. Nie są oni w stanie określić, czy studia na kierunku big data mają przyszłość. W większości nie potrafią również powiedzieć, kim jest data scientist (43\% odpowiedzi) oraz gdzie może taka osoba pracować (68,9\% odpowiedzi). Problemem okazało się także pytanie dotyczące umiejętności absolwentów kierunku analiza danych. Jedynie 4 respondentów zaznaczyło wszystkie możliwe odpowiedzi. Nie jest bowiem prawdą, że analityk danych to informatyk. Osoba ta musi być specjalistą z różnych dziedzin. Konieczna będzie zarówno znajomość informatyki (m.in. programowania i baz danych) oraz statystyki i ekonomii. Tak więc śmiało możemy stwierdzić, że jest to interdyscyplinarny specjalista, potrafiący łączyć wiele dziedzin nauki i wyciągać na tej podstawie wnioski.

Szkoda, że zarówno maturzyści, jak i już studiujący nie są zorientowani w ofertach dydaktycznych uczelni wyższych. Tylko 11 respondentów wskazało na SGH jako tę uczelnię, która w ofercie posiada studia na kierunku big data (w tym 7 maturzystów). Zaskakuje fakt, że aż 25 osób wskazało na Politechnikę Warszawską, mimo że nie posiada ona takiej oferty dydaktycznej. Być może jest to wynik silnej pozycji tej uczelni na rynku krajowym. Warto w tym momencie dodać, że od września 2015 roku studia związane z analizą danych wprowadziły:

- Uniwersytet Warszawski, Wydział Nauk Ekonomicznych: metody statystyczne w biznesie - wszystkie zajęcia mają charakter warsztatów;

- Szkoła Główna Handlowa w Warszawie: analizy statystyczne i data mining w biznesie - integralną część studiów stanowią zajęcia w laboratorium komputerowym oraz warsztaty zastosowań biznesowych; akademia analityka - analizy statystyczne i data mining w biznesie - studia skierowane są do pracowników zajmujących się zaawansowaną analityką w firmach komercyjnych, bankach, instytucjach nadzorczych czy admi- 
nistracji publicznej oraz pracowników naukowo-dydaktycznych uczelni wyższych pragnących poszerzyć swój warsztat naukowo-badawczy oraz dla absolwentów uczelni, którzy posiadają wykształcenie matematyczne, informatyczne, statystyczne i chcą dokształcić się w zakresie nowoczesnej analityki w zastosowaniach biznesowych; inżynieria danych - big data - wiedza specjalistyczna i umiejętności praktyczne niezbędne do identyfikowania, pozyskiwania, składowania i analizy danych o dużym wolumenie oraz do rozwiązywania związanych z tym problemów;

- Szkoła Główna Gospodarstwa Wiejskiego: systemy informacyjne i analiza danych - studia adresowane do każdego, kto w pracy zawodowej lub prywatnie chce wykorzystywać w sposób profesjonalny i efektywny bazy danych oraz metody przetwarzania i analizy danych; biostatystyka i analiza danych w ochronie zdrowia publicznego - pierwszy w Polsce kierunek studiów podyplomowych kompleksowo przygotowujących do pracy w charakterze biostatystyka, analityka danych biomedycznych posiadającego też kompetencje w zakresie programowania, przetwarzania i zarządzania danymi oraz bioinformatyki;

- Uniwersytet Ekonomiczny w Katowicach: analiza danych z wykorzystaniem narzędzi SAS - zajęcia prowadzone są przez analityków praktyków pracujących zawodowo z narzędziami SAS, głównie w sektorze bankowym i sektorze usług; BI z wykorzystaniem narzędzi SAS - celem jest zapoznanie studentów z kompleksowym podejściem do sfery przetwarzania analitycznego w przedsiębiorstwach w zakresie technologii Business Intelligence, metod raportowania i prezentacji danych, integracji i monitorowania systemów informatycznych, analiz wielowymiarowych, odkrywania wiedzy oraz dobrych praktyk związanych $\mathrm{z}$ wdrożeniem, zarządzaniem oraz wykorzystywaniem biznesowym tych rozwiązań;

- Uniwersytet Ekonomiczny w Poznaniu: studia z SAS - uczestnik studiów - oprócz dyplomu ukończenia studiów - ma również możliwość uzyskania certyfikatu stanowiącego dowód posiadania wysokich umiejętności analitycznych (www4).

\section{PODSUMOWANIE}

W tej części pracy spróbujemy podsumować nasze rozważania dotyczące big data. Specjaliści data science to nowy rodzaj analityków danych. Świetnie radzą sobie oni z technologią IT oraz charakteryzują się zdolnościami rozwiązywania istotnych kwestii biznesowych. To matematycy, informatycy i badacze w jednym. Specjaliści 
data science są dziś bardzo poszukiwani na rynku pracy i dobrze wynagradzani, m.in. dlatego, że posiadają unikalne umiejętności wsparcia zagadnień biznesowych $\mathrm{i}$ technologicznych. Jeszcze 10 lat temu nikt nie słyszał o specjalistach z zakresu data science. Gwałtowny wzrost popularności tej specjalizacji spowodowany jest zmianami rynkowymi i dynamicznym rozwojem cyfrowej gospodarki. Warto zauważyć, że zmienia się także podejście przedsiębiorstw do tematu zarządzania danymi $\mathrm{w}$ dobie big data. Firmy zdają sobie sprawę z tego, że konieczne jest uwzględnianie w ich działalności wszelkich dostępnych danych - zarówno wewnętrznych, jak i zewnętrznych, ustrukturyzowanych i nieustrukturyzowanych. Dają one istotne źródło przewagi konkurencyjnej. Oczywiście jedynie w przypadku, gdy instytucja potrafi je sprawnie pozyskać, zanalizować i wyciągnąć z nich wartościową wiedzę biznesową. W tym mają właśnie pomóc specjaliści data science.

Uczelnie wychodzą naprzeciw rosnącemu zapotrzebowaniu na specjalistów big data. W ofertach kształcenia uwzględniają one zmiany zachodzące na rynku pracy. Wprowadzają nowe kierunki studiów, mające kształcić osoby o interdyscyplinarnej wiedzy.

Widzimy zatem, że nie unikniemy dalszego rozwoju technologii, a tym samym coraz większego zainteresowania naszymi danymi. I choć niektórym z nas wydaje się, że może to mieć negatywny wpływ na nasze funkcjonowanie w środowisku gospodarki cyfrowej, to proces ten jest nieunikniony. Będziemy analizować dane, którymi dysponujemy, we wszystkich dziedzinach życia. I tak:

- na wiarygodność kredytową danej osoby może wpływać to, czy dany klient się rozwiedzie, czy będzie miał dziecko, czy słucha rapu (oczywiście bank może to przewidywać);

- firmy ubezpieczeniowe, widząc na portalu społecznościowym, że ich klient lubi sporty ekstremalne, może zmienić swoją ofertę;

- ZUS, urzędy skarbowe mogą zwiększyć efektywność swoich działań oraz wartość informacyjną swoich danych i prognoz przez korelacje danych $\mathrm{z}$ urzędów skarbowych z tymi z urzędów pracy;

- służba zdrowia może znacznie usprawnić system leczenia chorób przez zastosowanie domowych urządzeń pobierających informacje o naszych parametrach życiowych i postępach w leczeniu.

To tylko niektóre z licznych przykładów wykorzystania wiedzy data scientist. Szkoda tylko, że (jak wynika z przeprowadzonych badań) młodzi ludzie niewiele wiedzą o potrzebach cyfrowego świata. Aby iść z duchem czasu potrzeba większego zaangażowania całego społeczeństwa, a przede wszystkim uświadamiania obywateli. Trzeba uzmysłowić przeciętnemu Polakowi, że big data może być wykorzystywana w dobrych celach i w sposób nieinwazyjny dla obywateli. Może się to odbywać nawet za ich przyzwoleniem i pod ich kontrolą. Wszystko jest jedynie 
kwestią skonstruowania odpowiedniego prawa, które będzie regulować zbieranie i przetwarzanie danych. Powinno ono także oferować przejrzystość całego procesu zarządzania danymi.

\title{
LITERATURA
}

Fawcett T., Provost F., 2014, Analiza danych w biznesie. Sztuka podejmowania skutecznych decyzji. Gliwice, Helion.

Górniak J., Wachnicki J., 2010, Pierwsze kroki w analizie danych. Kraków, Predictive Solutions.

\section{NETOGRAFIA}

wwwl - http://bigdatacenter.pl/?page_id=16 [dostęp: 20.12.2015].

www2 - http://bigdatacenter.pl/?page_id=14 [dostęp: 20.12.2015].

www3 - http://oferta.sgh.waw.pl/pl/SitePages/OfertaDydaktyczna.aspx?PID=205\&ST $=$ magisterskie [dostęp: 21.12.2015].

www4 - http://itwiz.pl/9-kierunkow-ksztalcacych-specjalistow-od-data-science-polsce/ [dostęp: 29.12.2015].

\section{BIG DATA - STUDIES OF THE FUTURE}

\begin{abstract}
The aim of this paper is to show the importance of Big Data studies. The authors present some interesting results of their investigations. The article discusses the extent to which pupils and students are familiar with the latest developments of IT technology.
\end{abstract}

Keywords: big data, education, data scientist 